\title{
Successional dynamics of soil characteristics in a long fallow agricultural system of the high tropical Andes
}

\author{
J. Abadín ${ }^{\mathrm{a}}$, S.J. González-Prieto ${ }^{\mathrm{a}, *}$, L. Sarmiento ${ }^{\mathrm{b}}$, M.C. Villar ${ }^{\mathrm{a}}$, T. Carballas ${ }^{\mathrm{a}}$ \\ a Instituto de Investigaciones Agrobiológicas de Galicia, CSIC, Apartado 122, Avda de Vigo, s/n, E-15780 Santiago de Compostela, Spain \\ ${ }^{\mathrm{b}}$ Instituto de Ciencias Ambientales y Ecológicas, Facultad de Ciencias, Universidad de los Andes, Mérida 5101, Venezuela
}

Received 3 January 2002; received in revised form 18 June 2002; accepted 6 August 2002

\begin{abstract}
To detect soil changes related to vegetation and fertility restoration in a long fallow agricultural system of the Venezuelan Andes, 32 soil (A horizon, 0-15 cm depth) and litter characteristics were studied in plots at different stages of the fallow-cultivation cycle. Four sectors of the valley were sampled, each one including seven plots: recently ploughed after a long fallow period; 1 and 2 years under potato crop; 1, 4-5 and 8 years in fallow and natural vegetation. Each sector had similar topography, parent material and exposure to reduce the spatial heterogeneity that can hinder the synchronic analysis of the succession. Data of each sector were standardized before the statistics comparisons. Although all soils were acidic, those involved in the cropping cycle, or with only 1 year of fallow, had a significantly lower pH than the others, indicating that soil cultivation triggered off acidifying processes intense enough to overcome the strong buffering indices of the soils. These acidifying processes, facilitated by the acidity generating ions that widely dominate the desaturated CEC, are surely due to the stimulation of litter and soil organic matter mineralization after ploughing the soil and also to the $\mathrm{N}$ fertilization of the cultivated soils. The high soil contents of exchangeable $\mathrm{Al}^{3+}$ and free $\mathrm{Al}$ oxides suggest that $\mathrm{Al}$ plays an important role in SOM stabilization, lowering its mineralization. No successional increase of any main plant nutrient was found in soil or litter. Moreover, soil available $\mathrm{P}$ and litter-P contents are higher during the cultivation phase and at the beginning of the succession, probably as a consequence of fertilization. Water holding capacity was similar for all soils, indicating that this long fallow agriculture system does not change the water storage capability of the soil, an important aspect for the role of the páramo in the regional water balance. The main characteristics of soils and litters, including their $\delta{ }^{13} \mathrm{C}$ values, were useless to monitor soil changes during cultivation and fallowing. Nevertheless, the $\delta^{15} \mathrm{~N}$ values of SOM decreased steadily along the crop-fallow chronosequence, while those of litterfall were rather constant from recently ploughed to 1 year fallow soils, decreasing suddenly on medium fallow plots and again on the virgin páramo. Together, the $\delta^{15} \mathrm{~N}$ values of soil- and litter-N grouped the soils following the crop-fallow chronosequence, suggesting that a change from 'open' to 'closed' $\mathrm{N}$ cycling is the characteristic that better discriminates the soils along the succession. (C) 2002 Elsevier Science Ltd. All rights reserved.
\end{abstract}

Keywords: $\delta{ }^{13} \mathrm{C} ; \delta{ }^{15} \mathrm{~N}$; Fallow agriculture; Fertility restoration; Mountain agriculture; Páramo; Secondary succession; Spatial heterogeneity

\section{Introduction}

The highest vegetation belt of the Northern Andes, between the continuous timberline and the limit of glaciers $(3000-4800 \mathrm{~m})$, is occupied by the páramo ecosystem, which since the Pleistocene period has been colonized by plants and animals progressively adapted to the unique conditions of the cold tropics (van der Hammen, 1974). In this environment, until $4000 \mathrm{~m}$, a long fallow agricultural system, characterized by alternate short periods of cultivation (1-3 years) and long fallow periods (usually 5-10

\footnotetext{
* Corresponding author. Tel.: +34-981-590-958; fax: + 34-981-592-504.

E-mail address: serafin@iiag.cesga.es (S.J. González-Prieto).
}

years), is used by traditional farmers to produce potatoes and cereals. Globally, the intensification of the agriculture has reduced the area under long fallow systems; nevertheless, they are still widely employed around the world, especially in the humid tropical forests and in the puna and páramo ecosystems of the mountain areas of Asia, Africa and South America (Grigg, 1974; Ramakrishnan, 1992; Sarmiento et al., 1993; Hervé, 1994).

Long fallow agriculture persists in the páramo partly because the use of inorganic fertilizers does not prevent the sudden decrease of crop production and, thus, only allowing a limited reduction of the fallow period (Fajardo et al., 1975; Ferwerda, 1987; Sarmiento, 1995). In the Venezuelan Andes, a rapid fertility lost during the cultivation period 
has been reported, with average potato yields reducing from 18 to $5 \mathrm{tha}^{-1}$ along four consecutive years of cultivation despite the mineral fertilization (Sarmiento, 1995). During the fallow period a relatively fast secondary succession takes place, with vegetation changing from early stages strongly dominated by exotic herbs, like the European weed Rumex acetosella, to intermediate stages dominated by natives herbs such as the legume Lupinus meridanus (the only abundant $\mathrm{N}_{2}$ fixing species), to late successional stages dominated by giant caulescent rosettes and shrubs, the characteristic páramo life forms (Sarmiento et al., 2002). Multiple functions has been attributed to the long fallow period in this type of agriculture: (i) to recover soil fertility; (ii) to control crop diseases, pathogens, pests and weeds; and (iii) to maintain areas for extensive grazing and fuel wood and medicinal plant collection. Leaving aside what is the most important function of the fallow period, this agricultural system offers a unique opportunity to study secondary succession and ecosystem recovery in an open environment, where the successional driving forces are different from forest ecosystems which have been more widely studied. Particularly interesting is the analysis of soil changes and their relationships with vegetation development, an aspect usually neglected in studies of secondary succession.

Studies carried out during the secondary succession in the Colombian and Venezuelan páramo have not shown any significant change in the total soil $\mathrm{C}$ and $\mathrm{N}$, available inorganic nutrients or other edaphic properties that could be related to the restoration of fertility (Ferwerda, 1987; Aranguren and Monasterio, 1997; Llambí and Sarmiento, 1998; Jaimes, 2000).

The main methodological problems to analyse soil changes in the páramo during secondary succession are: (i) the high spatial heterogeneity of mountain soils, that limits the use of a synchronic approach; and (ii) the high soil organic matter (SOM) content, that masks the possible changes taking place in this short time scale. Considering these limitations, Sarmiento and Bottner (2002) analysed the labile fractions of soil $\mathrm{C}$ and $\mathrm{N}$ in two adjacent plots with similar environmental characteristics, but in contrasting stages of the fallow-cultivation cycle and found a successional increase in the soil $\mathrm{C}$ and $\mathrm{N}$ microbial biomass and in the potentially mineralizable $\mathrm{C}$ and $\mathrm{N}$, and a decrease in the proportion of nitrate in the mineral pool. Nevertheless, to extrapolate these results obtained in two plots to the whole system a large number of plots must be considered.

On the other hand, several authors have found relationships between the $\delta{ }^{15} \mathrm{~N}$ signature of litter and SOM and the characteristics of the $\mathrm{N}$ cycle in natural and managed ecosystems. Högberg et al. (1995) found that processes leading to loss of $\mathrm{N}\left(\mathrm{NH}_{3}\right.$ volatilization, $\mathrm{NO}_{3}^{-}$leaching, denitrification) discriminate against the heavy isotope ${ }^{15} \mathrm{~N}$. Koerner et al. (1999) reported that the mean $\delta{ }^{15} \mathrm{~N}$ of soil increased with the intensity of former land use and that the $\delta$ ${ }^{15} \mathrm{~N}$ of understorey plant and soil appear to be excellent tracers of previous land use in forests, and could be used in historical studies. Finally, Handley et al. (1999), Chang and Handley (2000) and Eshetu and Högberg (2000) concluded that both foliar and soil $\delta{ }^{15} \mathrm{~N}$ are related to the residence time of the whole ecosystem $\mathrm{N}$, declining with a change from 'open' to 'closed' $\mathrm{N}$ cycling.

The main objective of this study was to analyse soil changes during the secondary succession in the long fallow system of the páramo, that can be associated with vegetation development and fertility restoration. Two new approaches with regard to the previous works have been utilized: (i) to minimise the problem of soil spatial heterogeneity, a stratified sampling was performed in four small sectors of a valley, each sector including a complete crop-fallow chronosequence; and (ii) in addition to the main soil characteristics two new variables were introduced, the ${ }^{13} \mathrm{C}$ and ${ }^{15} \mathrm{~N}$ isotopic signatures of SOM and litter, probably more sensitive to short term changes in soil functioning.

\section{Material and methods}

\subsection{Study area}

The study was performed in the Páramo de Gavidia, located in the Northern Andes, Venezuela, between $8^{\circ} 35^{\prime}$ and $8^{\circ} 45^{\prime}$ of latitude $\mathrm{N}$ and between $70^{\circ} 52^{\prime}$ and $70^{\circ} 57^{\prime}$ of longitude W; and included within the Sierra Nevada de Mérida National Park, that comprises $2650 \mathrm{~km}^{2}$ of the Venezuelan Andes. The sampling was performed between 3350 and $3700 \mathrm{~m}$ a.s.l. in the small (approximately $5 \mathrm{~km}^{2}$ ) and narrow valley of Quebrada Piñuelas, of glacial origin, where agriculture is practised on the narrow river terraces, small alluvial fans and the rather steep mountain slopes (Smith, 1995). In this area the oldest geological formation of Venezuelan Andes appears, consisting of Pre-Cambrian schists and gneises originated by metamorphism of marine sediments during the orogenic process. The soils are generally acid, stony and sandy Inceptisols, formed after the retreat of the last glacier (approximately 15,000 years ago), with a high organic matter (OM) content, but low nutrient availability (Sarmiento et al., 1991).

Climate is characterized by a total rainfall of $1352 \mathrm{~mm}$ year $^{-1}$ which follows an unimodal pattern, with a dry season from November to March and a rainy season from April to October. The average annual air temperature is $8.4{ }^{\circ} \mathrm{C}$ at $3450 \mathrm{~m}$ a.s.l., with only $2.2^{\circ} \mathrm{C}$ of difference between the coldest and the warmest months, but with a mean daily thermic amplitude of $9.4{ }^{\circ} \mathrm{C}$.

The agricultural practices in this area include long fallow periods (5 to more than 10 years), after which the successional vegetation is incorporated into the soil by ploughing at a deepness of $20 \mathrm{~cm}$. The amount of total phytomass incorporated into the soil at ploughing has been estimated in $778 \mathrm{~g} \mathrm{~m}^{-2}$ for a 6 year fallow plot (Montilla et al., 2002) and $989 \mathrm{~g} \mathrm{~m}^{-2}$ for a 12 year old plot, of which 
$51 \%$ was aboveground biomass, $18 \%$ belowground biomass and $31 \%$ litter (Sarmiento, 1995). The phytomass was left to decompose during 4-5 months and then the plots are ploughed again, planted with potatoes and fertilized at sowing with granulated NPK (mean quantity: $1.8 \mathrm{t} \mathrm{ha}^{-1}$ of 16:16:08 NPK) supplied in a single dose. Potatoes, at a mean density of 4.44 plants $\mathrm{m}^{-2}$, are always the first crop after the fallow period and are cultivated for one or two consecutive years, with average yields of $18.3 \mathrm{tha}^{-1}$ the first year and $9.9 \mathrm{t} \mathrm{ha}^{-1}$ the second year. Before abandoning the plot a cereal (barley or wheat) is usually cropped without application of fertilizer.

\subsection{Methods}

To overcome soil spatial heterogeneity, an stratified sampling was performed using a database of 1200 fields with known crop-fallow status during the preceding 8 years (Smith 1995, updated to the year 2000). Four representative sectors were selected: Bárbara-Los Torres, Ramón, Los Yaques and Los Volcanes, which is a popular name at Gavidia for areas with rock avalanches and not related to volcanic activity. Each sector included plots in different stages of the succession located very close to each other, and in similar conditions of topography, parent material and sun exposure. In November 1998, it was collected for each sector a crop-fallow chronosequence of seven soils: rompedura $(\mathrm{R}$; recently ploughed soil after a long fallow period), 1 and 2 year potato crop (C-1 and $\mathrm{C}-2$, respectively), 1, 4 or 5 and 8 year fallow (F-1, F-4 and F8 , respectively) and virgin páramo (VP; never cultivated soil). At sampling, potatoes in the cultivated plots had been already harvested.

Soil samples were taken from the A horizon $(0-15 \mathrm{~cm}$ depth) with a stainless steel probe $(3.5 \mathrm{~cm}$ in dia). Fifteen sub-samples were taken at random from the whole area of each plot, mixed and thoroughly homogenized after sieving at $4 \mathrm{~mm}$. Plant debris (above ground litter + living and dead roots) retained on the $4 \mathrm{~mm}$ sieve were separated from the inorganic material, washed with deionized water, dried at $60{ }^{\circ} \mathrm{C}$, weighed, frozen with liquid $\mathrm{N}_{2}$, finely ground $(<125 \mu \mathrm{m})$ and kept for analyses.

The dry matter content of fresh soils and ground plant debris was assessed by oven-drying aliquots of them at $110^{\circ} \mathrm{C}$ for $5 \mathrm{~h}$. Soil water holding capacity was determined in a Richards membrane-plate extractor at a pressure corresponding to a matrix potential of $\mathrm{p} F$ 2. Soil texture was determined (on the $<2 \mathrm{~mm}$ soil fraction) by the international mechanical analysis method.

Soil $\mathrm{pH}$ was measured with a pH-meter (Metröhm, Switzerland) in $\mathrm{H}_{2} \mathrm{O}, \mathrm{KCl}$ and $p$-nitrophenol employing a soil/solution ratio of 1:2.5. Soil buffering index $(\beta)$ was calculated as follows: $\beta=10\left(7.0-\mathrm{pH}_{p \text {-nitrophenol }}\right) /$ (7.0- $\mathrm{pH}_{\mathrm{KCl}}$ ).

The soil exchangeable cations ( $\mathrm{H}, \mathrm{Na}, \mathrm{K}, \mathrm{Mg}, \mathrm{Ca}$ and $\mathrm{Al})$ were extracted as follows: $10 \mathrm{~g}$ of soil were mixed with $10 \mathrm{~g}$ of acid washed sand quartz $(100-500 \mu \mathrm{m})$ and percolated consecutively with $100 \mathrm{ml}$ of a solution of $0.17 \mathrm{M}\left(\mathrm{HOCH}_{2}\right.$ $\left.\mathrm{CH}_{2}\right)_{3} \mathrm{~N}$ and $0.12 \mathrm{M} \mathrm{BaCl}_{2}$ at $\mathrm{pH} 8.2$ and with $25 \mathrm{ml}$ of $0.12 \mathrm{M} \mathrm{BaCl}_{2}$, both extracts being mixed and adjusted to $250 \mathrm{ml}$ before analysis. To assess the $\mathrm{Fe}$ and $\mathrm{Al}$ free oxides, $5 \mathrm{~g}$ of soil were shaked $\left(20 \mathrm{~min}, 60^{\circ} \mathrm{C}\right)$ with $33 \mathrm{ml}$ of a solution $0.14 \mathrm{M} \mathrm{C}_{2} \mathrm{H}_{2} \mathrm{O}_{4}$ and $0.20 \mathrm{M}\left(\mathrm{COONH}_{4}\right)_{2} \cdot \mathrm{H}_{2} \mathrm{O}$ and with $1 \mathrm{~g}$ of $\mathrm{Na}_{2} \mathrm{~S}_{2} \mathrm{O}_{4}$; the supernatant was separated by centrifugation $(3 \mathrm{~min} \times 6400 \mathrm{~g})$ and the soil residue was extracted again, both extracts being mixed and adjusted to $100 \mathrm{ml}$ before analysis. Soil labile $\mathrm{P}$ was extracted by shaking $4 \mathrm{~g}$ of soil for $30 \mathrm{~min}$ with $120 \mathrm{ml}$ of $\mathrm{NaHCO}_{3}$ $0.5 \mathrm{M}$ at $\mathrm{pH}$ 8.5. Total $\mathrm{K}, \mathrm{Ca}, \mathrm{Mg}$ and $\mathrm{P}$ contents of litter (plant debris $>4 \mathrm{~mm}$ ) were assessed in milled material $\left(500 \mathrm{mg}\right.$ ) that was digested for $20 \mathrm{~min}$ with $1 \mathrm{ml}$ of $\mathrm{H}_{2} \mathrm{SO}_{4}$ (96\%) and $4 \mathrm{ml}$ of $\mathrm{HNO}_{3}(53 \%)$ in a high performance microwave digestion unit (Milestone 1200 mega, Sorisole, Italy). The $\mathrm{H}$ ions were measured by potentiometry, $\mathrm{Na}$ and $\mathrm{K}$ by atomic emission spectrophotometry and $\mathrm{Ca}, \mathrm{Mg}, \mathrm{Fe}$ and $\mathrm{Al}$ by atomic absorption spectrophotometry, whereas $\mathrm{P}$ was measured by the colorimetric method of Murphy and Riley (1962). The $\mathrm{C}$ and $\mathrm{N}$ contents of soils and litter, as well as their $\delta{ }^{13} \mathrm{C}$ and $\delta{ }^{15} \mathrm{~N}$ values, were measured on finely ground samples with an elemental analyser (EA) coupled on-line with an isotopic ratio mass spectrometer (Finnigan Mat, delta C, Bremen, Germany).

Data were statistically analysed by one-way ANOVA and honestly significant differences were established at $P<0.05$ using the Tukey's test (the Tamhane's T2 test in the case of unequal variances in the groups). The data were standardized by subtracting the mean value of the variable in the corresponding sector from the individual value of each soil. The relationships among the 22 physical, chemical and physico-chemical variables analysed in the 28 soils sampled were statistically studied by a factor analysis technique (SPSS statistical package); the goal of this statistical analysis was to identify: (i) the main factors that differentiate the soils, and (ii) the factors that characterize the soils under different cropping-fallowing stages. With the same objective, the relationships among the concentrations and total amounts of the major nutrients contained in the litterfall were also studied.

\section{Results}

\subsection{Soil characterization}

Table 1 shows for each chronosequence soil group the mean values and the standard deviations of the main soil characteristics. All the soils studied were acidic (Table 1), with values between 4.50 and 5.70 for $\mathrm{pH}$ in $\mathrm{H}_{2} \mathrm{O}$, between 3.80 and 4.66 for $\mathrm{pH}$ in $\mathrm{KCl}$ and between 5.10 and 5.74 for $\mathrm{pH}$ in $p$-nitrophenol. Two significantly $(P<0.001)$ different plot groups can be made according to their soil $\mathrm{pH}^{\text {in }} \mathrm{H}_{2} \mathrm{O}$ : (i) soils with medium-to-long fallow period (4-8 years) or 
Table 1

Main characteristics of the soils studied. The soils come from four valley sectors, each one including a complete crop-fallow chronosequence. The table shows, for each chronosequence soil group, the mean value of the variable and, into parentheses, the standard deviation

\begin{tabular}{|c|c|c|c|c|c|c|c|}
\hline \multirow[t]{2}{*}{ Soils } & \multicolumn{3}{|l|}{$\mathrm{pH}$} & \multirow[t]{2}{*}{ Buffering index } & \multirow[t]{2}{*}{$\mathrm{C}\left(\mathrm{g} \mathrm{kg}^{-1}\right.$ d.s. $)$} & \multirow[t]{2}{*}{$\mathrm{N}\left(\mathrm{g} \mathrm{kg}^{-1}\right.$ d.s. $)$} & \multirow[t]{2}{*}{$\mathrm{P}\left(\mu \mathrm{g} \mathrm{g}^{-1}\right.$ d.s. $)$} \\
\hline & $\mathrm{H}_{2} \mathrm{O}$ & $\mathrm{KCl}$ & $p$-Nitrophenol & & & & \\
\hline $\mathrm{R}$ & $4.82(0.11)$ & $4.17(0.29)$ & $5.27(0.16)$ & $6.11(0.38)$ & $80.4(15.8)$ & $4.5(0.8)$ & $12.9(6.8)$ \\
\hline $\mathrm{C}-1$ & $4.71(0.21)$ & $4.01(0.17)$ & $5.33(0.25)$ & $5.57(0.56)$ & $72.0(17.6)$ & $3.9(0.9)$ & $30.7(16.3)$ \\
\hline $\mathrm{C}-2$ & $4.84(0.09)$ & $3.91(0.09)$ & $5.24(0.10)$ & $5.72(0.34)$ & $76.2(22.2)$ & $4.6(1.2)$ & $26.9(19.5)$ \\
\hline F-1 & $4.97(0.27)$ & $4.08(0.12)$ & $5.39(0.18)$ & $5.51(0.47)$ & $71.5(15.4)$ & $4.0(0.6)$ & $19.6(8.4)$ \\
\hline $\mathrm{F}-4$ & $5.44(0.23)$ & $4.43(0.21)$ & $5.56(0.17)$ & $5.63(0.51)$ & $78.0(25.6)$ & $4.8(1.5)$ & $14.3(5.9)$ \\
\hline F-8 & $5.18(0.19)$ & $4.13(0.15)$ & $5.47(0.21)$ & $5.33(0.62)$ & $70.9(30.5)$ & $3.9(1.2)$ & $11.2(3.9)$ \\
\hline VP & $5.44(0.25)$ & $4.35(0.08)$ & $5.52(0.22)$ & $5.60(0.76)$ & 76.8 (30.7) & $4.1(1.6)$ & $3.3(2.9)$ \\
\hline \multirow[t]{3}{*}{ ALL } & $5.06(0.34)$ & $4.15(0.23)$ & $5.40(0.20)$ & $5.62(0.52)$ & $75.1(21.2)$ & $4.3(1.1)$ & $17.0(13.0)$ \\
\hline & \multicolumn{6}{|c|}{ Complex of exchangeable cations ( $\mathrm{cmol} \mathrm{kg}^{-1}$ d.s.) } & \multirow{2}{*}{$\begin{array}{l}\text { Base } \\
\text { saturation }(\%)\end{array}$} \\
\hline & $\mathrm{Na}^{+}$ & $\mathrm{K}^{+}$ & $\mathrm{Mg}^{2+}$ & $\mathrm{Ca}^{2+}$ & $\mathrm{H}^{+}$ & $\mathrm{Al}^{3+}$ & \\
\hline $\mathrm{R}$ & $0.04(0.01)$ & $0.12(0.32)$ & $0.62(0.28)$ & $7.52(4.18)$ & $44.29(10.10)$ & $12.33(1.92)$ & $14.2(4.4)$ \\
\hline C-1 & $0.03(0.01)$ & $0.27(0.08)$ & $0.78(0.44)$ & $7.86(2.20)$ & $39.85(13.29)$ & $11.34(3.78)$ & $20.2(11.7)$ \\
\hline $\mathrm{C}-2$ & $0.03(0.01)$ & $0.36(0.21)$ & $1.06(0.50)$ & $15.52(10.40)$ & $43.70(9.45)$ & $9.75(3.00)$ & $26.5(10.6)$ \\
\hline F-1 & $0.04(0.03)$ & $0.26(0.16)$ & $0.70(0.54)$ & $11.88(6.24)$ & $37.66(10.37)$ & $10.95(0.39)$ & $25.2(13.0)$ \\
\hline F-4 & $0.05(0.02)$ & $0.33(0.18)$ & $4.16(5.78)$ & $27.34(15.06)$ & $31.44(9.40)$ & $9.60(0.51)$ & $46.8(14.7)$ \\
\hline F-8 & $0.10(0.15)$ & $0.15(0.12)$ & $0.92(0.94)$ & $8.20(5.86)$ & $34.63(13.00)$ & $11.70(0.90)$ & $20.8(10.6)$ \\
\hline VP & $0.04(0.02)$ & $0.23(0.17)$ & $2.14(1.40)$ & $16.34(11.44)$ & $31.82(11.99)$ & $11.58(2.43)$ & $32.8(17.4)$ \\
\hline \multirow[t]{3}{*}{ ALL } & $0.05(0.06)$ & $0.25(0.16)$ & $1.52(2.40)$ & $13.74(10.44)$ & $37.38(11.01)$ & $10.98(2.16)$ & $26.6(13.1)$ \\
\hline & $\mathrm{Al}_{2} \mathrm{O}_{3}\left(\mathrm{~g} \mathrm{~kg}^{-1}\right.$ d.s. $)$ & $\mathrm{Fe}_{2} \mathrm{O}_{3}\left(\mathrm{~g} \mathrm{~kg}^{-1}\right.$ d.s. $)$ & \multicolumn{4}{|c|}{ Granulometric fractions ( $\mathrm{g} \mathrm{kg}^{-1}$ d.s.) } & \multirow{2}{*}{$\begin{array}{l}\text { Water holding } \\
\text { capacity } \\
\left(\mathrm{g} \mathrm{kg}^{-1} \text { d.s. }\right)\end{array}$} \\
\hline & & & Coarse sand & Fine sand & Silt & Clay & \\
\hline $\mathrm{R}$ & $29.7(5.7)$ & $28.3(9.0)$ & $344(102)$ & 269 (29) & $152(15)$ & $232(81)$ & $499(107)$ \\
\hline $\mathrm{C}-1$ & $24.9(6.8)$ & $25.6(6.9)$ & $328(101)$ & 328 (79) & 134 (19) & $210(64)$ & $465(86)$ \\
\hline $\mathrm{C}-2$ & $27.3(3.8)$ & $31.3(4.9)$ & $300(69)$ & $286(61)$ & $149(16)$ & $266(28)$ & $494(93)$ \\
\hline F-1 & $25.0(7.2)$ & $24.2(5.3)$ & $355(43)$ & $311(24)$ & $139(15)$ & $195(31)$ & $454(96)$ \\
\hline $\mathrm{F}-4$ & $22.1(6.1)$ & $25.4(3.8)$ & $284(69)$ & $354(120)$ & $137(9)$ & $225(61)$ & $516(105)$ \\
\hline F-8 & $26.8(9.4)$ & $24.8(5.6)$ & $352(56)$ & $300(75)$ & 150 (19) & $198(21)$ & $458(102)$ \\
\hline VP & $22.7(3.5)$ & $26.3(5.3)$ & 346 (75) & $344(55)$ & $134(30)$ & $181(63)$ & $469(142)$ \\
\hline ALL & $25.5(6.0)$ & $26.6(5.9)$ & $329(71)$ & $314(69)$ & $143(18)$ & $215(52)$ & $479(95)$ \\
\hline
\end{tabular}

Abbreviations: R, rompedura (recently ploughed soil after a fallow period); C-1 and C-2, soils after 1 and 2 year potato crop, respectively; F-1, F-4 and F-8, soils with a 1, 4 or 5 and 8 year fallow period, respectively; VP, virgin páramo (never cultivated soil); ALL, all soils; d.s., dry soil. 
Table 2

Litter amount and litter nutrient concentrations in the soils studied. The soils come from four valley sectors, each one including a complete crop-fallow chronosequence. The table shows, for each chronosequence soil group, the mean value of the variable and, into parentheses, the standard deviation

\begin{tabular}{|c|c|c|c|c|c|c|c|}
\hline Group & Litter ( $\mathrm{g} \mathrm{kg}^{-1}$ d.s. $)$ & $\mathrm{C}\left(\mathrm{mg} \mathrm{g}^{-1}\right)$ & $\mathrm{N}\left(\mathrm{mg} \mathrm{g}^{-1}\right)$ & $\mathrm{P}\left(\mathrm{mg} \mathrm{g}^{-1}\right)$ & $\mathrm{K}\left(\mathrm{mg} \mathrm{g}^{-1}\right)$ & $\operatorname{Mg}\left(\mathrm{mg} \mathrm{g}^{-1}\right)$ & $\mathrm{Ca}\left(\mathrm{mg} \mathrm{g}^{-1}\right)$ \\
\hline $\mathrm{R}$ & $3.22(0.53)$ & $385.75(58.68)$ & $11.34(1.14)$ & $1.54(0.27)$ & $4.16(1.47)$ & $2.89(1.41)$ & $12.70(5.11)$ \\
\hline $\mathrm{C}-1$ & $1.95(0.40)$ & $426.74(15.19)$ & $14.83(2.94)$ & $1.54(0.26)$ & $4.81(1.82)$ & $2.51(0.71)$ & $8.41(4.25)$ \\
\hline $\mathrm{C}-2$ & $2.15(0.14)$ & $443.66(19.16)$ & $13.58(1.76)$ & $1.63(0.44)$ & $4.69(1.76)$ & $2.03(0.60)$ & $12.40(3.79)$ \\
\hline F-1 & $3.18(0.84)$ & $425.41(13.81)$ & $11.00(1.41)$ & $1.83(0.35)$ & $5.78(1.19)$ & $2.57(0.22)$ & $8.32(3.27)$ \\
\hline F-4 & $3.61(0.56)$ & $436.60(11.25)$ & $11.84(0.16)$ & $1.30(0.56)$ & $3.95(1.88)$ & $2.35(0.66)$ & $9.36(2.42)$ \\
\hline F-8 & $3.63(2.20)$ & $431.41(56.81)$ & $10.08(1.01)$ & $1.61(0.66)$ & $5.14(3.64)$ & $3.10(0.66)$ & $12.56(8.65)$ \\
\hline VP & $6.28(3.20)$ & $456.79(29.53)$ & $8.20(2.28)$ & $0.62(0.27)$ & $3.25(1.72)$ & $2.17(0.65)$ & $10.20(6.63)$ \\
\hline ALL & $3.43(1.91)$ & $429.48(37.08)$ & $11.55(2.57)$ & $1.44(0.53)$ & 4.54 (1.98) & $2.52(0.77)$ & $10.56(5.00)$ \\
\hline
\end{tabular}

Abbreviations: R, rompedura (recently ploughed soil after a fallow period); C-1 and C-2, soils after 1 and 2 year potato crop, respectively; F-1, F-4 and F-8, soils with a 1, 4 or 5 and 8 year fallow period, respectively; VP, virgin páramo (never cultivated soil); ALL, all soils.

never cultivated (virgin páramo), with $\mathrm{pH} 5.35 \pm 0.24$ (mean $\pm \mathrm{SD}$ ); and (ii) recently ploughed, 1 or 2 years crop and 1 year fallow soils, with $\mathrm{pH} 4.87 \pm 0.25$. Differences among soil series were less significant for $\mathrm{pH}$ in $\mathrm{KCl}(P<$ 0.005 ) and not significant for $\mathrm{pH}$ in $p$-nitrophenol. Buffering index was very strong for rompedura soils and strong for all the other soils.

The total $\mathrm{C}$, total $\mathrm{N}$ and available $\mathrm{P}$ contents of the soils (Table 1) ranged from 45.6 to $118.0 \mathrm{~g} \mathrm{~kg}^{-1}, 3.2$ to $8.0 \mathrm{~g} \mathrm{~kg}^{-1}$ and 0.4 to $55.0 \mathrm{mg} \mathrm{kg}^{-1}$, respectively, without significant differences among soil series except for $\mathrm{P}$ content, which decreased in the order $\mathrm{C}-1>\mathrm{C}-2>\mathrm{F}-$ $1>$ F- $4>\mathrm{R}>\mathrm{F}-8>\mathrm{VP}$, although the differences were only significant $(P<0.05)$ between the virgin páramo and the 1 year crop $(\mathrm{C}-1)$ soils.

The amounts of exchangeable basic ions in the soils (Table 1) decreased in the order $\mathrm{Ca}^{2+}(14.0-$ $\left.458.0 \mathrm{mmol} \mathrm{kg}^{-1}\right)>\mathrm{Mg}^{2+}\left(1.4-128.0 \mathrm{mmol} \mathrm{kg}{ }^{-1}\right)>\mathrm{K}^{+}$ $\left(0.3-5.9 \mathrm{mmol} \mathrm{kg}^{-1}\right)>\mathrm{Na}^{+}\left(0.1-3.2 \mathrm{mmol} \mathrm{kg}^{-1}\right)$. In all the soils, the complex of exchangeable cations is widely dominated by the acidity generating $\mathrm{H}^{+}$ions (201.3$553.0 \mathrm{mmol} \mathrm{kg}{ }^{-1}$ ) and, to a lesser extend, by $\mathrm{Al}^{3+}$ (73.5-164.7 mmol kg $\left.{ }^{-1}\right)$; consequently, base saturation was always low $(4.24-58.74 \%)$.

The amount of free aluminium oxides in the soils (Table 1) ranged from 15.1 to $40.5 \mathrm{~g} \mathrm{~kg}^{-1}$. The free iron oxide contents $\left(16.5-36.6 \mathrm{~g} \mathrm{~kg}^{-1}\right)$ were similar to those for the aluminium and for both free oxide types there were no significant differences among soil series.

Sand was the most important granulometric fraction (Table 1), sand content (535-810 $\mathrm{g} \mathrm{kg}^{-1}$ ) being equally distributed between its coarse $\left(229-477 \mathrm{~g} \mathrm{~kg}^{-1}\right)$ and fine $\left(198-481 \mathrm{~g} \mathrm{~kg}^{-1}\right)$ subfractions. The clay fraction (96$296 \mathrm{~g} \mathrm{~kg}^{-1}$ ) was the third particle size fraction in importance and the silt $\left(94-169 \mathrm{~g} \mathrm{~kg}^{-1}\right)$ was the least important one. Therefore, all the soils studied were coarse textured (sandy loam, sandy clay loam and loamy sand), but their water holding capacities were high (298$622 \mathrm{~g} \mathrm{~kg}^{-1}$ ).

\subsection{Plant litter fall}

For both the litter mass (above ground litter + living and dead roots) and its $\mathrm{C}$ content, the values for the cultivated soils were slightly lower than those for the other soils, especially those from the never cultivated soil (virgin páramo), but differences were not statistically significant (Table 2). The macronutrient ( $\mathrm{N}, \mathrm{P}, \mathrm{Na}, \mathrm{K}, \mathrm{Ca}, \mathrm{Mg}$ ) concentrations in the litter (Table 2) did not differ significantly among the seven soil treatments considered, except for the litter-P content in the virgin páramo that was lower than in the plots involved in the crop and fallow cycle. The $\mathrm{C} / \mathrm{N}$ ratios ranged from 30 to 60 , with the lowest values in litter from soils after 1 year of cultivation, and the highest values in the never cultivated páramo, but again, the differences were not statistically significant among treatments.

\subsection{Fallow effect on the main soil characteristics}

The matrix of anti-image correlations (the negative of the partial correlation coefficients) was studied to find out and discard the soil variables inadequate for the factor analysis, which were the following: silt and litter content, $\mathrm{pH}$ in water and in $p$-nitrophenol, exchangeable $\mathrm{H}^{+}, \mathrm{Na}^{+}$ and $\mathrm{Al}^{3+}$, sum of exchangeable bases and total CEC. The discard of these variables did not imply the loss of key information on soil characteristics because two out of three granulometric fractions (sand and clay), the $\mathrm{C}$ and nutrient contents of litter, one $\mathrm{pH}$ measure $(\mathrm{pH}$ in $\mathrm{KCl}$ ) and also the buffering index, the exchangeable cations more important for plant nutrition $\left(\mathrm{K}^{+}, \mathrm{Mg}^{2+}\right.$ and $\left.\mathrm{Ca}^{2+}\right)$ and also the CEC base saturation (that reflects the relative importance of the acidity generating exchangeable $\mathrm{H}^{+}$and $\mathrm{Al}^{3+}$ cations) were kept for the factor analysis. After this, the Kaiser-Meyer-Olkin measure of sampling adequacy increased from an unacceptable value of 0.444 to a middling figure of 0.671 , and the Barlett's test of sphericity was significant at $P<0.001$. 
Table 3

Matrix of correlations between the soil variables and the first four factors obtained by a principal component analysis

\begin{tabular}{|c|c|c|c|c|}
\hline & \multicolumn{4}{|l|}{ Factor } \\
\hline & 1 & 2 & 3 & 4 \\
\hline $\mathrm{pH} \mathrm{KCl}$ & -0.132 & 0.675 & -0.478 & -0.460 \\
\hline Buffering index & 0.907 & 0.029 & 0.119 & -0.004 \\
\hline $\mathrm{C}($ total $)$ & 0.948 & 0.120 & 0.197 & -0.132 \\
\hline $\mathrm{N}$ (total) & 0.896 & 0.271 & 0.204 & -0.067 \\
\hline $\mathrm{P}$ (available) & -0.304 & -0.128 & 0.035 & 0.899 \\
\hline $\mathrm{K}^{+}$(exchangeable) & 0.145 & 0.660 & 0.175 & 0.665 \\
\hline $\mathrm{Mg}^{2+}$ (exchangeable) & 0.179 & 0.866 & 0.165 & -0.082 \\
\hline $\mathrm{Ca}^{2+}$ (exchangeable) & 0.382 & 0.892 & 0.081 & 0.084 \\
\hline Base saturation of CEC & 0.123 & 0.950 & 0.024 & 0.127 \\
\hline Al free oxides & 0.633 & -0.534 & 0.372 & -0.133 \\
\hline Fe free oxides & 0.066 & 0.057 & 0.906 & 0.127 \\
\hline Sand & -0.392 & -0.014 & -0.876 & 0.024 \\
\hline Clay & 0.347 & 0.084 & 0.905 & 0.060 \\
\hline Water holding capacity & 0.865 & 0.236 & 0.338 & -0.065 \\
\hline
\end{tabular}

Table 3 shows the matrix of correlations between the variables and the first four factors, obtained using a principal component analysis as the extraction method and the normalization Varimax with Kaiser as the rotation method. The percentage of the total variance explained by factors $1-4$ was $30.4,27.0,21.3$ and $11.1 \%$, respectively.

Factor 1 was defined on its positive extreme by the OM content $(\mathrm{C}, \mathrm{N})$ and the variables that influence it (Al oxides, that stabilize the OM) or that were strongly influenced by it (buffering index, water holding capacity). Only the sand and available $\mathrm{P}$ contents appeared on the negative arm of factor 1 with moderate correlation coefficients (Table 3); both variables influence the OM content by enhancing its mineralization (aeration and nutrient richness favour microbial activity) and sandy textures also reduces the physical protection of OM. Therefore, along factor 1 soil samples were differentiated following their contents of OM and the variables that influence the $\mathrm{C}$ and $\mathrm{N}$ stabilizationdecomposition balance.

The complex of exchangeable cations (base saturation, $\mathrm{Ca}, \mathrm{Mg}$ and $\mathrm{K}$ content), and $\mathrm{pH}_{\mathrm{KCl}}$ as a related variable, defined the positive arm of factor 2 , its negative arm being mainly determined by the $\mathrm{Al}$ oxides content. Factor 2, thus, will separate the soil samples according to their richness in exchangeable nutrients and $\mathrm{Al}$ oxides.

In factor 3, a strong polarization was found between the variables that define the positive arm (clay and Fe oxide contents) and those that define the negative one (sand content and, to a lesser extent, $\mathrm{pH}_{\mathrm{KCl}}$ ). Consequently, factor 3 will classify the soils according mainly to their texture.

Factor 4 was defined on its positive extreme by the available $\mathrm{P}$ and the exchangeable $\mathrm{K}$ contents, and in the opposite arm by $\mathrm{pH}_{\mathrm{KCl}}$, which is related to the acidification produced by $\mathrm{N}$ fertilization and the nitrification process. Therefore, the soil samples will be classified along factor 4 according to the availability of the main plant nutrients $(\mathrm{N}$, $\mathrm{P}, \mathrm{K})$ and, thus, to the fertilization effect.

The distribution of soil samples on the planes defined by the first three factors (Fig. 1A and B) was not related to the cropping-fallowing ages of the plots. The same was true for the planes that include the fourth factor (Fig. 1C), although this one differentiated the cultivated soils from the soils under fallow.

Trying to overcome this problem, the data were standardized by subtracting the mean value of the variable in the corresponding sector from the individual value of each soil and factor analysis was repeated. Unfortunately, no clear trends were observed with the transformed variables (data not shown) because the spatial heterogeneity is high not only inter-sectors, but also intra-sectors.

\subsection{Fallow effect on litterfall quantity and quality}

According to the criteria of Kaiser (1974), the KaiserMeyer-Olkin measure of sampling adequacy had an unacceptable value of 0.468 when all the variables were considered, a miserable value of 0.541 if only the variables of nutrient concentrations in the litter were selected and a nearly meritorious value of 0.787 when only the total amounts of nutrients contained in the litter (expressed in a dry soil basis) were used for factor analysis. Unfortunately, any of the factors extracted with these analyses differentiated the plots of different cropping-fallowing ages (data not shown). The same was true for factors extracted with the factor analyses made with the data standardized by subtracting the mean value of the variable in the corresponding sector from the individual value of each soil.

Comparison of Tables 1 and 2 showed that litter (aboveground litter + living and dead roots) constituted a very important reservoir of $\mathrm{P}$ and $\mathrm{K}$, a quite important pool of $\mathrm{Mg}$ and $\mathrm{C}$ and a lesser important pool of $\mathrm{Ca}$, because the absolute amounts of these elements contained in the litter were equivalent, on average, to $44 \%$ of soil available P, $25 \%$ of soil exchangeable $\mathrm{K}^{+}, 4 \%$ of soil exchangeable $\mathrm{Mg}^{2+}$, $2 \%$ of soil total $\mathrm{C}$ and $1.2 \%$ of soil exchangeable $\mathrm{Ca}^{2+}$. Although the litter $\mathrm{N}$ pool is small in absolute amount (it represents $0.7 \%$ of total soil $\mathrm{N}$ ), its contribution to the available $\mathrm{N}$ pool may be relatively important.

\section{5. $\delta{ }^{13} C$ and $\delta{ }^{15} N$ of litter and soil organic matter}

Table 4 shows the $\delta{ }^{13} \mathrm{C}$ and $\delta{ }^{15} \mathrm{~N}$ values for SOM and litter in the plots studied. The ${ }^{13} \mathrm{C}$ and ${ }^{15} \mathrm{~N}$ isotopic signatures of $\mathrm{OM}$ and litter showed wide intra-sector variations in the plot types, the only significant $(P<0.05)$ difference in $\delta{ }^{15} \mathrm{~N}$ values of litter being found between virgin páramo and rompedura and 4 year fallow plots. When the isotopic data were standardized, the $\delta{ }^{13} \mathrm{C}$ values in soil and litter did not show any clear tendency along the crop-fallow cycles. Conversely, the standardized $\delta{ }^{15} \mathrm{~N}$ of the SOM showed a steady decrease along the crop-fallow 

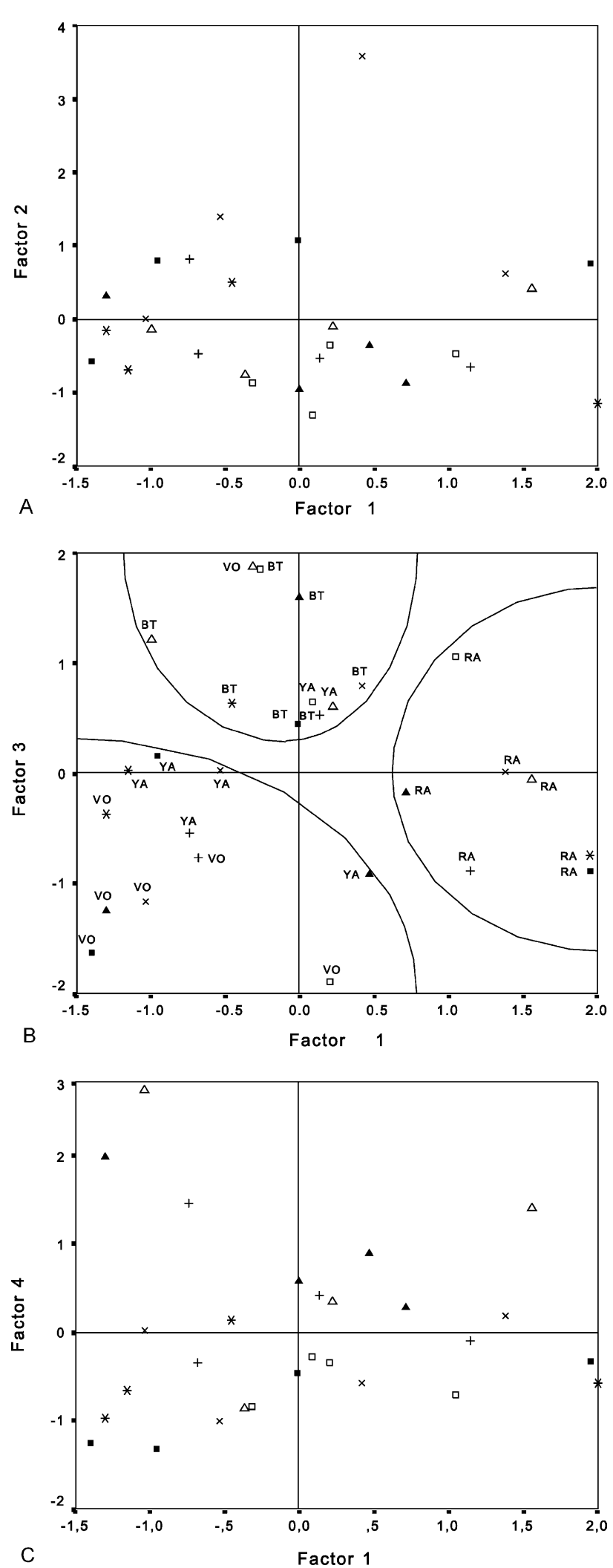

Fig. 1. Factor analysis of the main soil characteristics. Location of the soil samples on the planes defined by factors 1 and 2 (A), 1 and 3 (B) and 1 and 4 (C). Key: $\square=\mathrm{R}$, rompedura (recently ploughed soil after a fallow period); $\boldsymbol{\Delta}=\mathrm{C}-1,1$ year potato crop soil; $\Delta=\mathrm{C}-2,2$ year potato crop soil; $+=\mathrm{F}-$ 1,1 year fallow soil; $X=F-4,4$ or 5 year fallow soil; $*=F-8,8$ year fallow soil; $\mathbf{\square}=\mathrm{VP}$, virgin páramo (never cultivated soil). chronosequence; on the other hand, the standardized $\delta{ }^{15} \mathrm{~N}$ values of the litterfall were rather constant from rompedura soils to 1 year fallow soils, decreasing suddenly on 4 year fallow plots and again on the virgin páramo.

When the standardized values of plot vs sector mean for both $\delta{ }^{15} \mathrm{~N}$ of soil $\mathrm{N}$ and $\delta{ }^{15} \mathrm{~N}$ of litter $\mathrm{N}$ were plotted together, the soils were approximately grouped according to the crop-fallow chronosequence (Fig. 2). On the first quadrant, only plots involved in the cultivation cycle were located: (i) all the rompedura soils; (ii) half of the 1 year crop soils; and (iii) all the 2 year crop soils. Three out of four of the short fallow plots and one of the medium fallow plots were located on the second and fourth quadrants, near the origin of both axis and occupying an intermediate position between the cropped plots and the medium to long fallow plots. On the third quadrant, most of the medium to long fallow plots were located in a group nearby the origin of both axis, whereas all the virgin páramo soils appeared clearly grouped at the centre of the quadrant. Finally, two 1 year crop soils and one 1 year fallow soil appeared as outliers.

\section{Discussion}

As previously reported in other studies on páramo agroecosystems (Ferwerda, 1987; De Robert, 1993; Malagón, 1982, 1995; Llambí and Sarmiento, 1998), all the soils were acidic; however, the acidity presented a clear tendency to decrease along the succession. Although it is only of moderate importance ( 0.5 units), the significant decrease of the $\mathrm{pH}$ during the cropping cycle indicates that soil cultivation triggered acidifying processes intense enough to overcome the strong buffering index of the soils; these acidifying processes are surely due to the stimulation of litter and SOM mineralization after ploughing the soil and also to the $\mathrm{N}$ fertilization of the cultivated soils. The soil acidification in the cultivated páramo, also suggested by the results of Llambí and Sarmiento (1998) and Morales (2000), may be favoured by the active nitrification observed in these soils (Sarmiento, 1995; Sarmiento and Bottner, 2002; unpublished data from the authors). The abundance of acidity generating ions $\left(\mathrm{H}^{+}\right.$and $\left.\mathrm{Al}^{3+}\right)$, that widely dominate the soil complex of exchangeable cations, also may favour the soil acidification processes because an important fraction of these ions are easily displaced from the CEC to the soil solution, as indicated by the high difference between $\mathrm{pH}-\mathrm{H}_{2} \mathrm{O}$ and $\mathrm{pH}-\mathrm{KCl}$ (mean value 0.91 units of $\mathrm{pH}$ ). The interpretation of $\mathrm{pH}$ results is that cultivation approaches the soils to their potential acidity, which is higher than the present soil acidity of fallow soils.

The soil content of exchangeable basic ions decreased in the order $\mathrm{Ca}^{2+}>\mathrm{Mg}^{2+}>\mathrm{K}^{+}>\mathrm{Na}^{+}$, as it is usual in soils (Duchaufour, 1987), and base saturation was always low (Table 1), all the soils being desaturated according to criteria of Duchaufour (1987). 
Table 4

$\delta^{13} \mathrm{C}$ and $\delta^{15} \mathrm{~N}$ values of SOM and litter in the soils studied. The soils come from four valley sectors, each one including a complete crop-fallow chronosequence. The table shows, for each chronosequence soil group, the mean value of the variable and, into parentheses, the standard deviation

\begin{tabular}{llllr}
\hline Group & $\delta{ }^{13} \mathrm{C}$ soil & $\delta{ }^{13} \mathrm{C}$ litter & $\delta{ }^{15} \mathrm{~N}$ soil & \multicolumn{1}{c}{$\delta{ }^{15} \mathrm{~N}$ litter } \\
\hline $\mathrm{R}$ & $-22.66(0.81)$ & $-27.48(0.50)$ & $6.42(1.30)$ & $1.95(0.70)$ \\
$\mathrm{C}-1$ & $-23.17(1.37)$ & $-27.50(0.26)$ & $5.70(1.63)$ & $1.54(1.79)$ \\
$\mathrm{C}-2$ & $-23.11(0.61)$ & $-27.83(0.15)$ & $5.83(0.94)$ & $1.95(0.90)$ \\
F-1 & $-23.83(0.37)$ & $-27.92(0.21)$ & $5.35(0.79)$ & $2.16(1.41)$ \\
F-4 & $-23.28(0.36)$ & $-27.45(0.85)$ & $5.20(0.55)$ & $0.56(0.39)$ \\
F-8 & $-23.54(0.50)$ & $-27.61(0.61)$ & $5.15(0.93)$ & $0.63(0.74)$ \\
VP & $-23.74(0.50)$ & $-26.85(0.58)$ & $4.62(0.72)$ & $-0.87(0.38)$ \\
ALL & $-23.33(0.74)$ & $-27.51(0.56)$ & $5.47(1.06)$ & $1.13(1.37)$ \\
\hline
\end{tabular}

Abbreviations: R, rompedura (recently ploughed soil after a fallow period); C-1 and C-2, soils after 1 and 2 year potato crop, respectively; F-1, F-4 and F-8, soils with a 1, 4 or 5 and 8 year fallow period, respectively; VP, virgin páramo (never cultivated soil); ALL, all soils.

The exchangeable $\mathrm{Al}^{3+}$ content largely surpassed in all plots the maximum amount $\left(45 \mathrm{mmol} \mathrm{kg}{ }^{-1}\right)$ reported for Colombian páramo soils by Ferwerda (1987) and the amount of free aluminium oxides in the soils surpassed in all cases the threshold of $10 \mathrm{~g} \mathrm{~kg}^{-1}$ from which the net mineralization rate of soil $\mathrm{N}$ decreases significantly (González-Prieto et al., 1996). Therefore, aluminium likely plays in these soils an important role in the OM dynamics, lowering its mineralization.

The amounts of total and mineral $\mathrm{N}$, total $\mathrm{C}$, available $\mathrm{P}$ and exchangeable bases were within the ranges reported for long fallow agricultural systems of the Northern Andes (Ferwerda, 1987; Sarmiento and Monasterio, 1993;

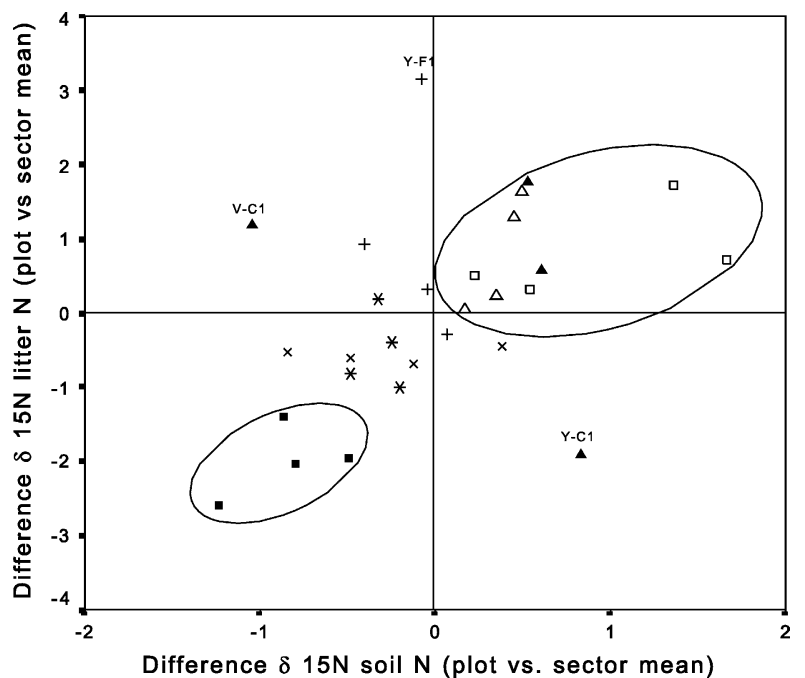

Fig. 2. Distribution of soil samples following their standardized $\delta{ }^{15} \mathrm{~N}$ values of SOM and litter. Standardization was made by subtracting the mean value of the variable in the corresponding valley sector from the individual value of each soil. Key: $\square=\mathrm{R}$, rompedura (recently ploughed soil after a fallow period); $\boldsymbol{\Lambda}=\mathrm{C}-1,1$ year potato crop soil; $\Delta=\mathrm{C}-2,2$ year potato crop soil; $+=\mathrm{F}-1,1$ year fallow soil; $\times=\mathrm{F}-4,4$ or 5 year fallow soil; $*=\mathrm{F}-8,8$ year fallow soil; $\mathbf{\square}=\mathrm{VP}$, virgin páramo (never cultivated soil).
Aranguren and Monasterio, 1997; Llambí and Sarmiento, 1998). As also reported these authors, no successional increase of any of the main plant nutrients was found in the soils. Moreover, the soil available $\mathrm{P}$ content, increased by fertilization in the cropped soils, decreased along the succession; nevertheless, the only significant difference was found between 1 year crop soils and virgin páramo, which, as also reported Llambí and Sarmiento (1998), showed the lowest available P content.

Although all the soils studied were coarse textured, their water holding capacities were high due to their high $\mathrm{OM}$ contents. The lack of significant differences in soil water holding capacity between the virgin páramo and the different cropping and fallowing phases indicates that the long fallow agriculture practised in the study area does not modify this parameter that is important for the regional water balance, in which the páramo plays a key role, largely controlling the availability of water in the lowlands (Hofstede, 1995; Sarmiento, 2000).

From the results of factor analyses, it is clear that the first three factors, that jointly explained $78.7 \%$ of total variance, are useless to differentiate the plots of different croppingfallowing ages. Factor 4, which explained another $11.6 \%$ of total variance, only differentiated cultivated soils from soils under fallow, but it did not discriminate between soils of different cropping or fallowing ages (Fig. 1). This implies that the soil variables analysed, that characterize the main general properties of the soils, are not useful to monitor the changes in soil fertility during the cropping and long fallowing cycles. This is likely due to the high spatial heterogeneity of the soils in the valley, because the soil samples from each sector appeared clearly grouped on the plane defined by factors 1 and 3 (Fig. 1B): (i) all soils from Ramón's sector around the positive arm of factor 1; (ii) all soils from Bárbara-Torres' sector (with three soils from Volcanes' and Yaques' sectors) around the positive arm of factor 3; and (iii) the other 11 soils from the right margin of Quebrada Piñuelas (Volcanes' and Yaques' sectors) grouped mainly on the third quadrant.

The absence of successional trends in most of the studied soil parameters can be explained considering that: (i) the use of a stratified sampling did not fully overcome the problem of soil spatial heterogeneity, which is high not only in intersectors, but also in intra-sectors and masks possible changes in soil characteristics; and (ii) the classic soil physical and chemical characteristics, with the relative exception of $\mathrm{pH}$ and exchangeable bases, are not sensitive to the changes in soil functioning at the time scale of secondary succession.

The feedback between plant litter fall and nutrient cycling processes plays a major role in the regulation of nutrient availability and net primary production in terrestrial ecosystems (Scott and Binkley, 1997). Nevertheless, the litter mass (above ground litter + living and dead roots) of the plots did not differ significantly along the chronosequence; the litter mass values were comparable to those of belowground biomass and litter previously found in fallow 
and virgin páramo plots from the same area by using specific macro sampling procedure to collect the macronecromass (Sarmiento, 1995; Montilla et al., 2002). No significant differences among plot types were found for the litter content in $\mathrm{C}$ and main macronutrients $(\mathrm{N}, \mathrm{P}, \mathrm{Na}, \mathrm{K}, \mathrm{Ca}$, $\mathrm{Mg}$ ), except for the litter-P content in the virgin páramo that, as occurred with soil available $\mathrm{P}$, was lower than in the plots involved in the crop and fallow cycle, likely due to the fertilization of cultivated soils. The lowest $\mathrm{C} / \mathrm{N}$ ratio of plant litter was found in litter from soils after 1 year of cultivation, also likely due to soil fertilization at the beginning of the cropping cycle.

As the processes leading to $\mathrm{N}$ losses (ammonia volatilization, nitrate leaching and denitrification) discriminate against the heavy isotope ${ }^{15} \mathrm{~N}$ (Högberg et al., 1995), the foliar and soil $\delta{ }^{15} \mathrm{~N}$ are related to the residence time of the whole ecosystem $\mathrm{N}$, decreasing from open to closed $\mathrm{N}$ cycles (Handley et al., 1999; Koerner et al., 1999; Chang and Handley, 2000; Eshetu and Högberg, 2000). Taking into account these considerations and the results found for the $\delta$ ${ }^{15} \mathrm{~N}$ signature of litter and SOM, it appears that a change from open to closed $\mathrm{N}$ cycling is the characteristic that better discriminates the soils under different stages of the cropfallow chronosequence. Moreover, the change from open to close cycling, not only for $\mathrm{N}$, but also for other nutrients, is supported by several evidences:

1. The early stages of the secondary succession that takes place during the fallow period is strongly dominated by the European weed $R$. acetosella (Sarmiento et al., 2002), a non-mycorrhizal species, whereas along the succession the number of species associated with MVA increased (Montilla et al., 1992), as well as the abundance and diversity of mycorrhizae. This indicates that there is a successional increase in the efficiency of the nutrient uptake by the plants, to which also contributes the successional increase of plant diversity through the coexistence of species with different patterns of soil exploration, both spatially and temporarily.

2. The only abundant $\mathrm{N}_{2}$ fixing species (L. meridanus) has its peak at intermediate stages of the succession (Sarmiento et al., 2002). The negative $\delta{ }^{15} \mathrm{~N}$ value of the $\mathrm{N}_{2}$ fixed by $L$. meridanus and its high $\mathrm{N}_{2}$ fixation rate $\left(-1.00 \delta{ }^{15} \mathrm{~N} ; 83.5 \%\right.$ of Lupinus- $\mathrm{N}$ derived from the atmosphere in field conditions; unpublished data from the authors) contributes decisively to the decline of soil and litter $\delta{ }^{15} \mathrm{~N}$ along the crop-fallow chronosequence.

3. During the succession, pioneer species are progressively replaced by giant caulescent rosettes and shrubs, the characteristic páramo life forms, which have specialized mechanisms for the conservation of nutrients, whose cycles become progressively closed. The genus Espeletia, for example, has a multiple set of adaptations including the maintenance of the dead leaves attached to the stem, where a decomposition system is maintained that allows the reutilization of the mineralized nutrient by the plant and prevents losses by leaching (Garay et al., 1981; Monasterio and Sarmiento, 1991).

4. A decrease of the nitrate/ammonium ratio in the inorganic-N pool was found along the succession in the study area and can be interpreted as a consequence of a successional decrease of nitrification (Sarmiento, 1995; Llambí and Sarmiento, 1998; Sarmiento and Bottner, 2002). The same tendency has been reported during secondary succession in other ecosystems (Schmitz et al., 1989; Clein and Schimel, 1995). The reduction of the nitrification rate will reduce $\mathrm{NO}_{3}-\mathrm{N}$ losses by lixiviation and denitrification, contributing to close $\mathrm{N}$ cycling.

In synthesis, our results suggested that: (i) this long fallow agriculture system provokes, during the cultivation phase, a transient increase in soil acidity and main nutrients availability, but does not modify the water storage capability of soils, an important aspect for the role of the páramo in the regional water balance; (ii) the soil richness in $\mathrm{Al}^{3+}$ and free $\mathrm{Al}$ oxides suggests that $\mathrm{Al}$ plays an important role in SOM dynamics, lowering its mineralization; (iii) the main general properties of soils and litters, with the relative exception of $\mathrm{pH}$ and nutrient availability, were useless to monitor soil changes during cultivation and fallowing, likely due to their insensibility to soil changes at the time scale of secondary succession or to the high spatial heterogeneity of these mountain soils; and (iv) the $\delta{ }^{15} \mathrm{~N}$ values of soil- and litter-N grouped the soils following the crop-fallow chronosequence, suggesting that the characteristic which better discriminates the soils along the secondary succession is a change from open to closed $\mathrm{N}$ cycling. This change agrees with previous evidences on the successional increase in the plant community efficiency to uptake (including $\mathrm{N}_{2}$ fixation), conserve and reutilize the nutrients, whose cycles become progressively closed.

\section{Acknowledgments}

We thank Julia Smith for her invaluable assistance in plot selection using her database of fields with known cropfallow status, Nelson Márquez and Bernabé Torres for assistance in field work, and José Salmonte, Angela Martín, Nélida Leite and José $\mathrm{M}^{\mathrm{a}}$ Calvo for technical assistance in the laboratory. This research was framed within the INCODC programme of the European Union through the contract number ERBIC18CT98-0263 and was also supported by CYTED (project XII.4). The isotopic ratio mass spectrometer was partly financed by the European Regional Development Fund (EU).

\section{References}

Aranguren, A., Monasterio, M., 1997. Aspectos de la dinámica del nitrógeno en parcelas con diferente tiempo de descanso en el Páramo de Gavidia (Andes Venezolanos). In: Liberman, M., Baied, C. (Eds.), 
Desarrollo sostenible en ecosistemas de montaña: manejo de las áreas frágiles de los Andes, Universidad de las Naciones Unidas, La Paz, pp. $171-181$.

Chang, S.X., Handley, L.L., 2000. Site history affects soil and plant N15 natural abundances (Delta N-15) in forests of northern Vancouver Island, British Columbia. Functional Ecology 14, 273-280.

Clein, J.S., Schimel, J.P., 1995. Nitrogen turnover and availability during succession from alder to poplar in Alaskan taiga forest. Soil Biology \& Biochemistry 27, 743-752.

De Robert, P., 1993. Prácticas campesinas en el Páramo de Apure: fundamentos ecológicos, económicos y sociales de un sistema de producción andino (Cordillera de Mérida, Venezuela). PhD Thesis, University of Los Andes, Mérida, Venezuela.

Duchaufour, P., 1987. Manual de edafología, Masson, Barcelona, 214 pp..

Eshetu, Z., Högberg, P., 2000. Effects of land use on N-15 natural abundance of soils in Ethiopian highlands. Plant and Soil 222, 109-117.

Fajardo, D., González, S., Hernández, C., Jimeno, M., Siabatto, T., 1975. Estudio socio-económico del valle alto del río Tunjuelo, Monografía del Centro de Investigaciones para el Desarrollo, Universidad Nacional de Colombia, 127 pp.

Ferwerda, W., 1987. The Influence of Potato Cultivation on the Natural Bunchgrass páramo in the Colombian Cordillera Oriental, Internal Report No. 220, Hugo de Vries Laboratory, Department of Palynology and Palaeo/Actuo-Ecology, University of Amsterdam, 83 pp.

Garay, I., Sarmiento, L., Monasterio, M., 1981. Le paramo désértique: éléments biogénes, peuplements des microarthropodes et stratégies de survie de la végétation. Comptes rendus du VIIIe Coloque International de Zoologie du Sol, Louvain-La-Neuve, Belgique, $127-134$.

González-Prieto, S.J., Cabaneiro, A., Villar, M.C., Carballas, M., Carballas, T., 1996. Effect of soil characteristics on $\mathrm{N}$ mineralization capacity in 112 native and agricultural soils. Biology and Fertility of Soils 22, $252-260$.

Grigg, D.B., 1974. The Agricultural Systems of the World. An Evolutionary Approach, Cambridge University Press, London, 358 pp.

Handley, L.L., Austin, A.T., Robinson, D., Scrimgeour, C.M., Raven, J.A., Heaton, T.H.E., Schmidt, S., Stewart, G.R., 1999. The N-15 natural abundance (Delta N-15) of ecosystem samples reflects measures of water availability. Australian Journal of Plant Physiology 26, 185-199.

Hervé, D., 1994. Desarrollo sostenible en los Andes Altos: los sistemas de cultivos con descanso largo pastoreado. In: Hervé, D., Genin, D., Riviére, G. (Eds.), Dinámicas del descanso de la tierra en los Andes, IBTA-ORSTOM, La Paz, pp. 155-169.

Hofstede, R.G.M., 1995. The effects of grazing and burning on soil and plant nutrient concentrations in Colombian páramo grasslands. Plant and Soil 173, 111-132.

Högberg, P., Johannisson, C., Högberg, M., Högbom, L., Näsholm, T., Hällgren, J.E., 1995. Measurements of abundances of ${ }^{15} \mathrm{~N}$ and ${ }^{13} \mathrm{C}$ as tools in retrospective studies of $\mathrm{N}$ balances and water stress in forests: $\mathrm{A}$ discussion of preliminary results. Plant and Soil 168-169, 125-133.

Jaimes, V., 2000. Estudio ecológico de una sucesión secundaria y de los mecanismos de recuperación de la fertilidad en un ecosistema de páramo. Master Thesis, Postgrado de Ecología Tropical, Facultad de Ciencias, Universidad de los Andes, Mérida, Venezuela.

Kaiser, H.F., 1974. An index of factorial simplicity. Psychometrika 39, $31-36$.

Koerner, W., Dambrine, E., Dupouey, J.L., Benoit, M., 1999. Delta N-15 of forest soil and understorey vegetation reflect the former agricultural land use. Oecologia 121, 421-425.

Llambí, L.D., Sarmiento, L., 1998. Biomasa microbiana y otros parámetros edáficos en una sucesión secundaria de los páramos venezolanos. Ecotrópicos 11, 1-14.
Malagón, D., 1982. Evolución de suelos en el páramo andino (NE del Edo. Mérida, Venezuela), CIDIAT, Mérida, Venezuela.

Malagón, D., 1995. Suelos de Colombia: Origen, evolución, clasificación y uso, Instituto Geográfico Agustín Codazzi, Santafe de Bogotá, Colombia.

Monasterio, M., Sarmiento, L., 1991. Adaptive radiation of Espeletia in the cold Andean tropics. Trends in Ecology \& Evolution 6, 387-391.

Montilla, M., Herrera, R.A., Monasterio, M., 1992. Micorrizas vesículoarbusculares en parcelas que se encuentran en sucesión-regeneración en los Andes tropicales. Suelo y Planta 2, 59-70.

Montilla, M., Monasterio, M., Sarmiento, L., 2002. Dinámica sucesional de la fitomasa y los nutrientes en parcelas en sucesión-regeneración en un agroecosistema de páramo. Ecotrópico 15 in press.

Morales, J., 2000. Macroinvertebrados edáficos en una sucesión secundaria del Páramo de Gavidia, Mérida, Venezuela. Tesis de grado, Licenciatura en Biología, Facultad de Ciencias, Universidad de los Andes, Mérida, Venezuela.

Murphy, J., Riley, J.P., 1962. A modified single solution method for the determination of phosphate in natural waters. Analytical Chemistry Acta 27, 31-36.

Ramakrishnan, P.S., 1992. Shifting Agriculture and Sustainable Development: An Interdisciplinary Study from North-Eastern India, UNESCO, Paris, $424 \mathrm{pp}$.

Sarmiento, L., 1995. Restauration de la fertilité dans un syst me agricole jach re longue des hautes Andes du Venezuela. PhD Thesis, Université de Paris-Sud, 236 pp.

Sarmiento, L., 2000. Water balance and soil loss under long fallow agriculture in the Venezuelan Andes. Mountain Research and Development 20, 246-253.

Sarmiento, L., Bottner, P., 2002. Carbon and nitrogen dynamics in two soils with different fallow times in the high tropical Andes: indications for fertility restoration. Applied Soil Ecology 19, 79-89.

Sarmiento, L., Monasterio, M., 1993. Elementos para la interpretación ecológica de un sistema agrícola campesino en los Andes venezolanos (Páramo de Gavidia). In: Rabey, M., (Ed.), El uso tradicional de los recursos naturales en monta as: tradición y transformación, IUBS/ UNESCO, Montevideo.

Sarmiento, L., Monasterio, M., Montilla, M., 1991. Succession, regeneration and stability in high andean ecosystems and agroecosystems: the rest-fallow strategy in the Páramo de Gavidia, Mérida, Venezuela. Geographica Bernesia, African Studies Series A8, 151-157.

Sarmiento, L., Monasterio, M., Montilla, M., 1993. Ecological bases, sustainability and current trends in traditional agriculture in the Venezuelan high Andes. Mountain Research and Development 13, 611-618.

Sarmiento, L., Llambí, L.D., Escalona, A., Marquez, J., 2002. Vegetation patterns, regeneration rates and divergence in an old-field succession of the high tropical Andes. Plant Ecology in press.

Schmitz, M.F., Yuste, P., Bermúdez de Castro, F., Pineda, F.D., 1989. Microorganisms of carbon and nitrogen cycles: variation during succession in a Mediterranean pasture. Revue d'Écologie et Biologie du Sol 26, 371-389.

Scott, N.A., Binkley, D., 1997. Foliage litter quality and annual net N mineralization: Comparison across North American forest sites. Oecologia 111, 151-159.

Smith, J.K., 1995. Die Auswirkungen der Intensivierung des Ackerbaus im Paramo de Gavidia—Landnutzungswandel an der oberen Anbaugrenze in den venezolanischen Anden, Diplomarbeit, Geographisches Institut, Universität Bonn.

Van der Hammen, T., 1974. The Pleistocene changes of vegetation and climate in tropical South America. Journal of Biogeography 1, 3-26. 